\title{
Research on influence of modification on structure and mechanical properties of manganese-iron brass CuZn40Mn3Fe
}

\author{
Badania wpływu modyfikacji \\ na strukturę i właściwości mechaniczne \\ mosiądzu manganowo-żelazowego CuZn40Mn3Fe
}

\begin{abstract}
Research on the modification of manganese-iron brass CuZn40Mn3Fe with the use of variable additions of titanium and boron have shown that these additives cause fragmentation (refinement) of the structures (grains and precipitates of phase $\alpha$ ) and an increase in the amount of precipitations of phase $\alpha$ in the brass structure. As a result of this modification, growth in the brass impact resistance (from $40 \mathrm{~J} / \mathrm{cm}^{2}$ to $46-48 \mathrm{~J} / \mathrm{cm}^{2}$ ) and tensile strength (from $400 \mathrm{MPa}$ to $509 \mathrm{MPa}$ ) are achieved.
\end{abstract}

Keywords: modification, structure, mechanical properties, manganese-iron brass

\section{Streszczenie}

Badania nad modyfikacją mosiądzu manganowo-żelazowego CuZn40Mn3Fe zmiennymi dodatkami tytanu i boru wykazały, że dodatki te powodują rozdrobnienie struktury (ziarn i wydzieleń fazy $\alpha$ ) oraz zwiększenie w strukturze mosiądzu ilości wydzieleń fazy $\alpha$. W efekcie modyfikacji

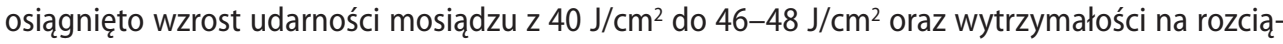
ganie z $400 \mathrm{MPa}$ do $509 \mathrm{MPa}$.

Słowa kluczowe: modyfikacja, struktura, właściwości mechaniczne, brąz manganowo-żelazowy

\section{Introduction}

Brass MM55 (CuZn40Mn3Fe) belongs to a group of special brasses. It has relatively high mechanical properties and very good corrosion resistance, including in marine environments. It also features relatively good bearing properties and the possibility of soldering with solder alloys (called "soft" and "hard"). Due to these favorable properties, MM55 brass is used in the construction of machine parts, equipment, and parts for the marine industry, such as fittings and ship propellers [1, 2].

Remigiusz Romankiewicz Ph.D. Eng., Ferdynand Romankiewicz Ph.D.D.Sc. Eng.: University of Zielona Góra, Faculty of Mechanical Engineering, Zielona Góra, Poland; r.romankiewicz@ibem.uz.zgora.pl 
Brass MM55 has a multiphase structure. Next to the $\beta$ solid solution in the structure are present $\alpha$ solid solution and iron oxide. The $\alpha$ phase separates upon the cooling of the primary crystallized solid solution $\beta$. This phase separation process occurring in the acicular form is relatively slow, while the secretion phase of the iron oxide is much faster [3, 4].

It is assumed that the fragmentation of the original structure brass MM55 and the secreting phases resulting from the surgery modifications micro-additives should contribute to favorable changes in the structure and mechanical properties of the alloy [5]. Based on the literature $[6,7]$, it is assumed that the good effect of modifying the brass can be obtained using a complex modifier containing boron and titanium.

\section{Modification of brass MM55}

For the study, the technical brass with the following chemical composition was used: $56.74 \% \mathrm{Cu} ; 3.55 \% \mathrm{Mn} ; 0.88 \% \mathrm{Fe} ; 0.19 \% \mathrm{~Pb} ; 0.10 \% \mathrm{Al} ; 0.06 \% \mathrm{Sn} ; 0.01 \% \mathrm{Ni} ; 0.009 \% \mathrm{P}$; $0.004 \% \mathrm{Si}$; and $0.002 \% \mathrm{Bi}$ (the remainder was zinc).

It was decided to check the influence of the type and amount of modifier used on the titanium and boron in the form of master alloys CuTi30 and CuB2.

The melting of brass was carried out in an induction furnace using a graphite-chamotte crucible coated with magnesium oxide based on water glass. Modification treatments were carried out with an overheating melt to a temperature of $1323 \mathrm{~K}$.

\section{Methods of research}

In order to determine the effects of modifying the tested brass, samples for the measurement of mechanical properties were casted in metal molds ( $\mathrm{PN}-67 / \mathrm{H}-87901)$. The tensile strength and elongation of the brass was defined in the static tensile test according to PN-91/H-04319. The hardness of the brass was specified in the Brinell test according to $\mathrm{PN}-91 / \mathrm{H}-04350$. Studies were also carried out on the impact strength of the brass on notched specimens " $\mathrm{u}$ " PN-EN10045-1.

To study the structure of the brass, cylindrical samples were cast in the metal mold with a diameter of $30 \mathrm{~mm}$ and height of $45 \mathrm{~mm}$. Metallographic specimen were performed on transverse cross-sections of the samples. Brass macrostructure observations were made at a magnification of 1.5 times, while observations of the microstructure were made using a Neophot-2 optical microscope at a magnification of 250 times. The profile breakthroughs of the impact resistance tests were also tested.

The morphology of the research breakthroughs was performed using a Jeol JSM $5600 \mathrm{LV}$ scanning electron microscope. 


\section{Results of research}

\subsection{Mechanical properties}

The indicators of the mechanical properties of the tested brass are provided in Table 1.

Table 1. Mechanical properties of brass MM55

\begin{tabular}{|c|l|c|c|c|c|}
\hline $\begin{array}{c}\text { No. of } \\
\text { melt }\end{array}$ & \multicolumn{1}{|c|}{ State of alloy } & $\begin{array}{c}\boldsymbol{R}_{\boldsymbol{m}^{\prime}} \\
\mathbf{M P a}\end{array}$ & $\begin{array}{c}\mathbf{A}_{\mathbf{5}} \\
\%\end{array}$ & $\mathbf{H B}$ & $\begin{array}{c}\boldsymbol{K} \mathbf{C U} \\
\mathbf{J} / \mathbf{c m}^{\mathbf{2}}\end{array}$ \\
\hline 1 & without modification & 400 & 17.5 & 145 & 40 \\
\hline 2 & modified with $0.01 \% \mathrm{~B}$ and $0.025 \% \mathrm{Ti}$ & 509 & 25 & 147 & 46 \\
\hline 3 & modified with $0.02 \% \mathrm{~B}$ and $0.05 \% \mathrm{Ti}$ & 476 & 23 & 147 & 48 \\
\hline
\end{tabular}

The data presented in Table 1 shows that the most-advantageous increase in tensile strength $R_{m}$ brass occurred after modification additives $0.01 \% \mathrm{~B}$ and $0.025 \% \mathrm{Ti}$ (up $27 \%$ ) while $15 \%$ increase in impact resistance $K C U$. Increasing the addition of the modifier to $0.02 \% \mathrm{~B}$ and $0.05 \% \mathrm{Ti}$ caused a $19 \%$ increase in tensile strength $R_{m}$ and a $20 \%$ increase in impact resistance $K C U$. In both cases, there was a favorable increase of the elongation $\mathrm{A}_{5}$, which was $43 \%$ for brass melt 2 and $31 \%$ for brass melt 3 . Analysis of the achieved strength parameters allows for a statement that the good effect of the modification of the tested brass supplement provides $0.01 \% \mathrm{~B}$ and $0.025 \% \mathrm{Ti}$. Increasing the modifier amounts to $0.02 \% \mathrm{~B}$ and $0.05 \% \mathrm{Ti}$ only resulted in a slight increase in impact strength while decreasing the tensile strength.

\subsection{Structure of brass CuZn40Mn3Fe}

The macrostructure of the examined brass is illustrated in Figures 1a, 2a, 3a. The brass in a non-modified state (Fig. 1a) had a relatively fine macrostructure with grain sizes of 150-210 microns. Samples of the modified brass (Figs. 2a and 3a) exhibited grain sizes within a range of 60-120 microns.

The microstructures of the samples of the tested brass are illustrated in Figures $1 \mathrm{~b}$, $2 \mathrm{~b}, 3 \mathrm{~b}$. The brass in a non-modified state (Fig. $1 \mathrm{~b}$ ) is characterized by a relatively small amount of $\alpha$ phase precipitates, some of which showing the shape of acicular. The ferric phase precipitates were characterized by a considerable size. The samples of brass after modification (Figs. $2 b$ and $3 b$ ) were characterized by a higher share of $\alpha$ phase precipitates and more-rounded shapes.

The ferric phase precipitates showed a considerably reduced size as related to those in the unmodified brass. The presented insights indicate that the modification of brass with micro-additives of titanium and boron resulted in a fragmentation of the ferric phase, facilitating the evolution of phase $\alpha$ from phase $\beta$. 
a)

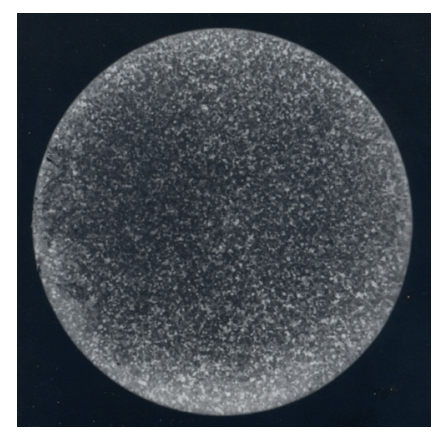

b)

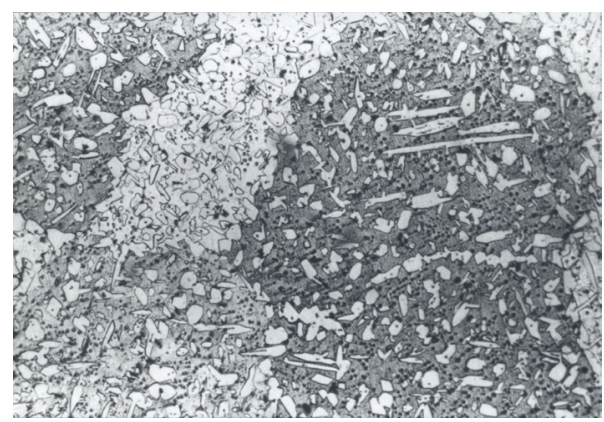

Fig. 1. Structure of brass CuZn40Mn3Fe: a) macrostructure (magn. 1.5×); b) microstructure (magn. 250X)

a)

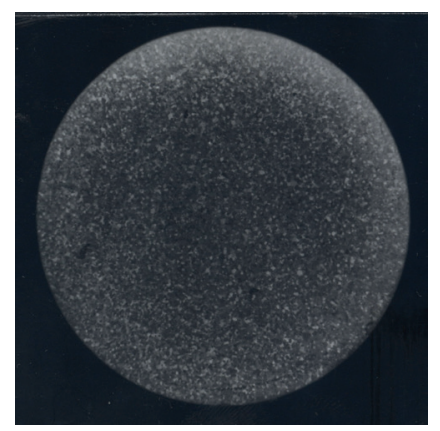

b)

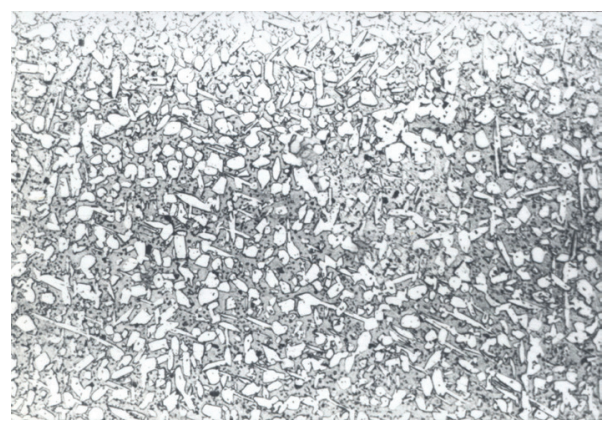

Fig. 2. Structure of brass CuZn40Mn3Fe modified with $0.01 \%$ B and $0.025 \%$ Ti: a) macrostructure (magn. 1.5 $\times$ ); b) microstructure (magn. 250×)

a)

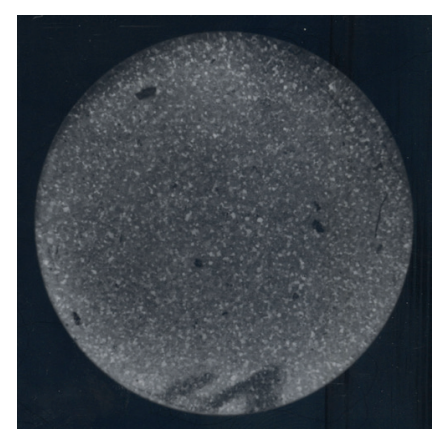

b)

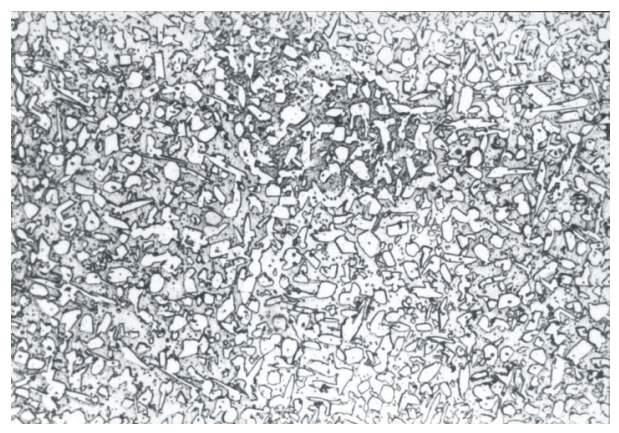

Fig. 3. Structure of brass CuZn40Mn3Fe modified with $0.02 \%$ B and 0.05\% Ti: a) macrostructure (magn. 1.5 X); b) microstructure (magn. 250×) 
The influence of the structure on breakthrough samples of the tested brass with impact resistance tests is illustrated in Figures 4-9. From a comparison of the fracture surface morphology (Figs. 4, 6, and 8), it appears that the fractures of the modified brass samples (Figs. 6 and 8) are characterized by a greater extension of the surface than the brass sample in the non-modified state (Fig. 4). Profile breakthroughs (Figs. 5, 7, and 9) showed that a breakthrough in the unmodified brass (Fig. 5) is followed mainly by phase $\beta$, while for the modified brass (Figs. 7 and 9), the breakthrough is followed by a large share of phase $\alpha$, which explains the achieved increase in the impact resistance of the brass after modification with micro-additives of boron and titanium.

a)

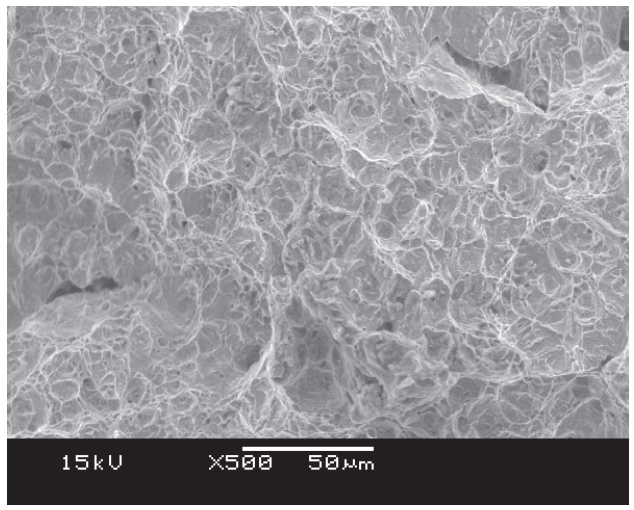

b)

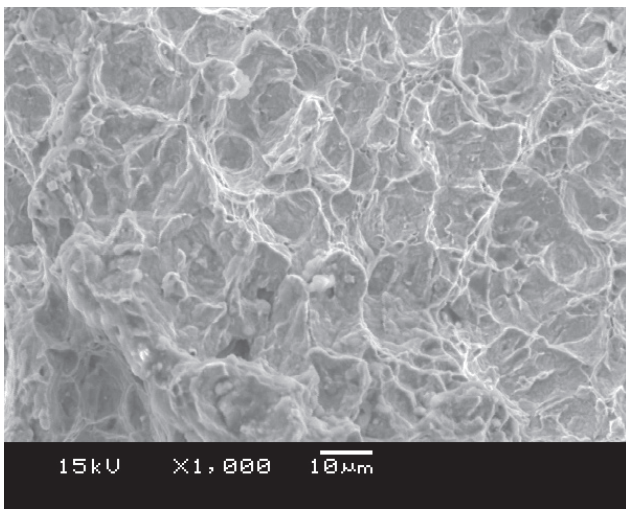

Fig. 4. Surface of breakthrough of brass CuZn40Mn3Fe: a) magn. 500x; b) magn. 1000x

a)

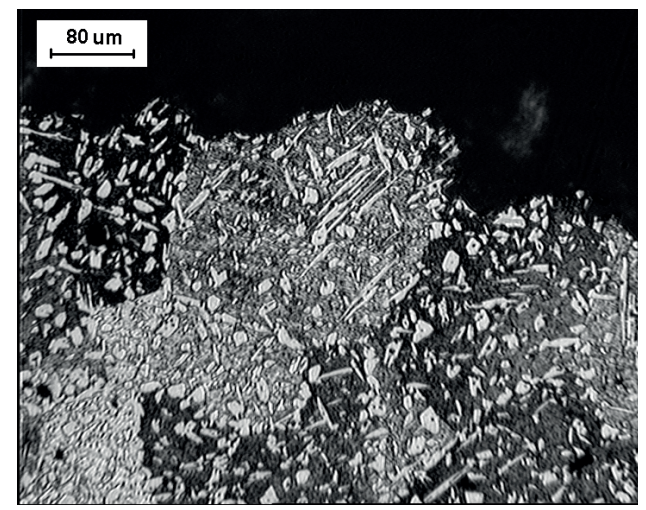

b)

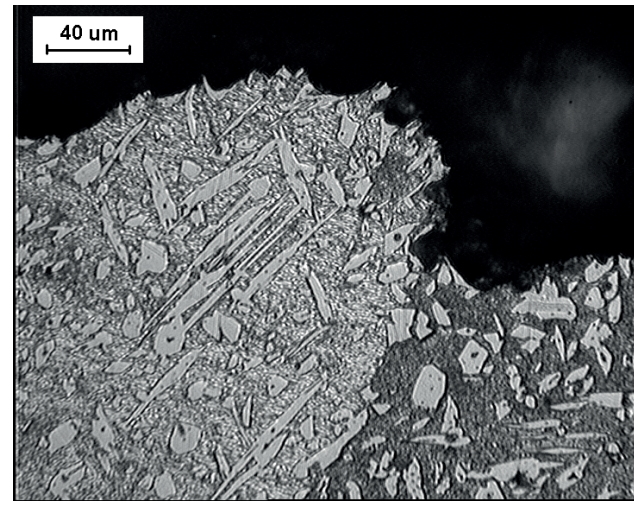

Fig. 5. Profile of breakthrough of brass CuZn40Mn3Fe: a) magn. 250x; b) magn. 500x 
a)

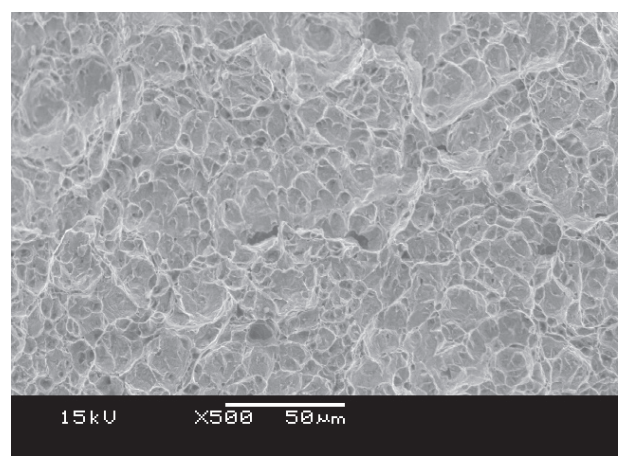

b)

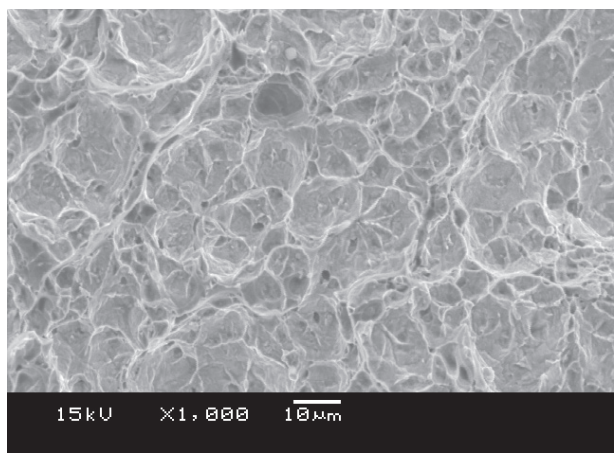

Fig. 6. Surface of breakthrough of brass CuZn40Mn3Fe modified with $0.01 \%$ B and $0.025 \%$ Ti: a) magn. $500 x$; b) magn. $1000 x$

a)

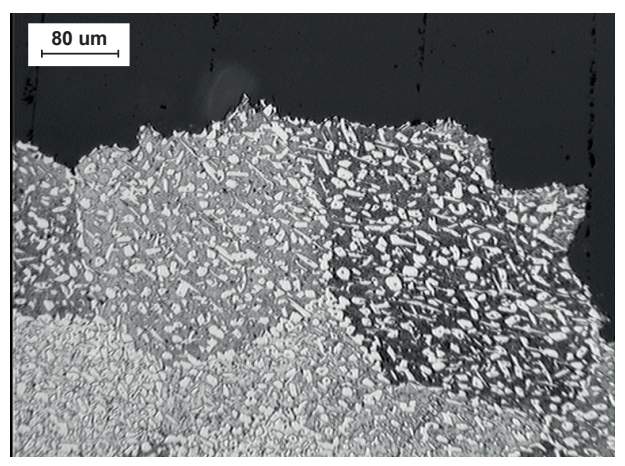

b)

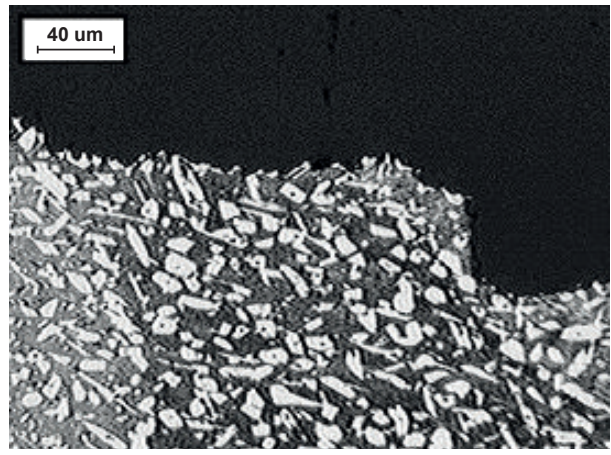

Fig. 7. Profile of breakthrough of brass CuZn40Mn3Fe modified with $0.01 \%$ B and $0.025 \%$ Ti: a) magn. 250x; b) magn. 500x

a)

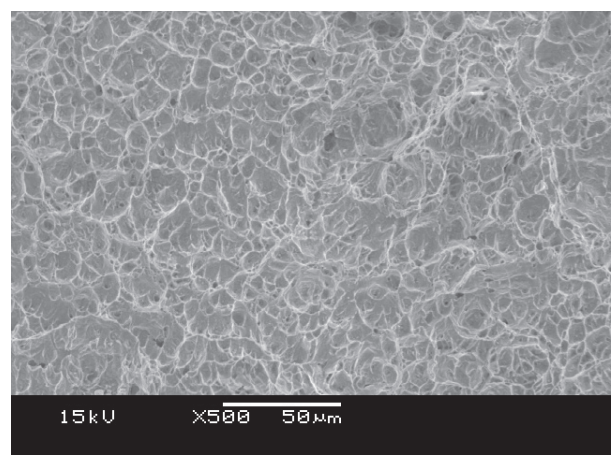

b)

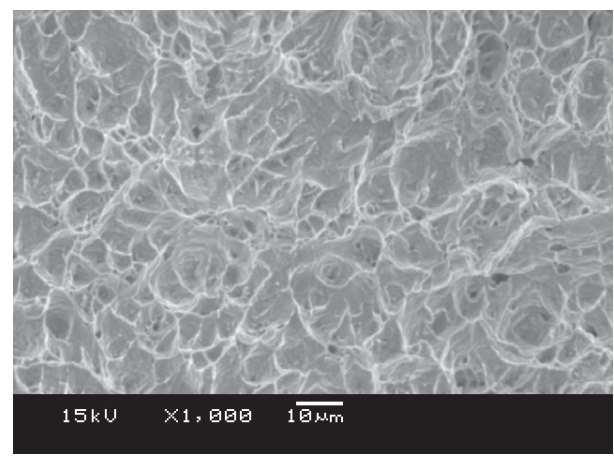

Fig. 8. Surface of breakthrough of brass CuZn40Mn3Fe modified with $0.02 \%$ B and $0.05 \%$ Ti: a) magn. 500x; b) magn. 1000x 
a)

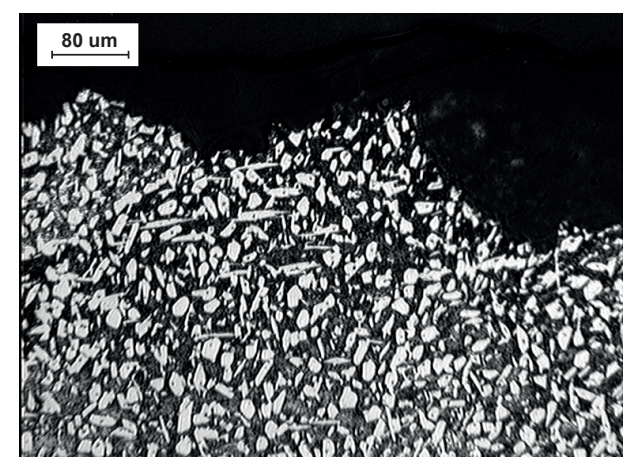

b)

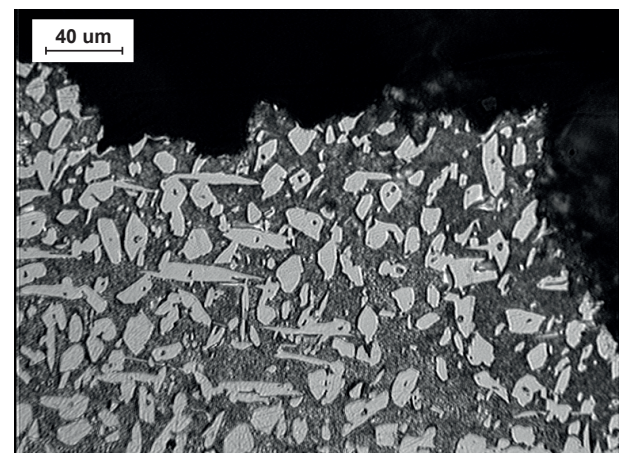

Fig. 9. Profile of breakthrough of brass CuZn40Mn3Fe modified with $0.02 \%$ B and $0.05 \%$ Ti: a) magn. 250x; b) magn. 500x

\section{Conclusions}

Treatment modifications of brass CuZn40Mn3Fe with variable micro-additives of boron and titanium resulted in a fragmentation of the grains of brass and iron oxide phase precipitates and increased the share in the structure of the alloy precipitate phase $\alpha$. The addition of $0.02 \% \mathrm{~B}$ and $0.05 \%$ Ti caused an increase from $400 \mathrm{MPa}$ to $476 \mathrm{MPa}$ in the brass tensile strength and an increase from $40 \mathrm{~J} / \mathrm{cm}^{2}$ to $48 \mathrm{~J} / \mathrm{cm}^{2}$ in its impact resistance. However, the optimal effect of the modification was achieved with the addition of $0.01 \% \mathrm{~B}$ and $0.025 \% \mathrm{Ti}$, causing an increase in tensile strength to $509 \mathrm{MPa}$ with an increase to $46 \mathrm{~J} / \mathrm{cm}^{2}$ in the impact resistance. An increase from $17.5 \%$ to $25 \%$ in the elongation of $A_{5}$ also occurred.

\section{References}

[1] Guss aus Kupfer und Kupferlegierungen. GDM, DG, DKI, Düsseldorf, Berlin 1982

[2] Górny Z.: Odlewnicze stopy metali nieżelaznych. Wydawnictwa Naukowo-Techniczne, Warszawa 1992

[3] Brunhuber E.: Guss aus Kupferlegierungen. Fachverlag Scheile \& Schön GmbH, Berlin - New York - Heidelberg 1967

[4] Wieland-Buch Kupferwerkstoffe. Wieland-Werke AG, Ulm 1986

[5] Romankiewicz F.: Krzepnięcie miedzi i jej stopów. PAN Poznań, WSI Zielona Góra 1995

[6] Adamski C., Rzadkosz S.: Metalurgia i odlewnictwo metali nieżelaznych, cz. Il: Stopy cynku oraz stopy miedzi. Skrypty Uczelniane AGH Nr 1312, Kraków 1992

[7] Romankiewicz F.: Modyfikacja miedzi i jej stopów. PAN Poznań, Politechnika Zielonogórska, Poznań Zielona Góra 1999 